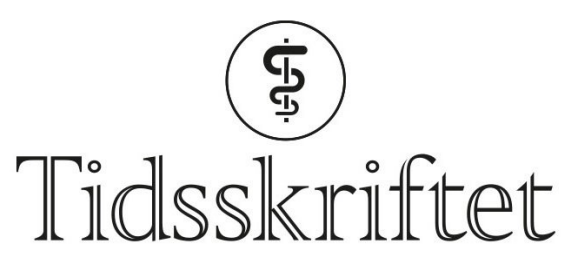

DEN NORSKE LEGEFORENING

\title{
DOAK-interaksjoner øker risiko for blødning
}

FRA ANDRE TIDSSKRIFTER

PETTER MORTEN PETTERSEN

Tidsskriftet

Bruk av DOAK-preparater i kombinasjon med andre medikamenter med samme nedbrytningsvei kan gi økt risiko for store blødninger, viser ny studie.

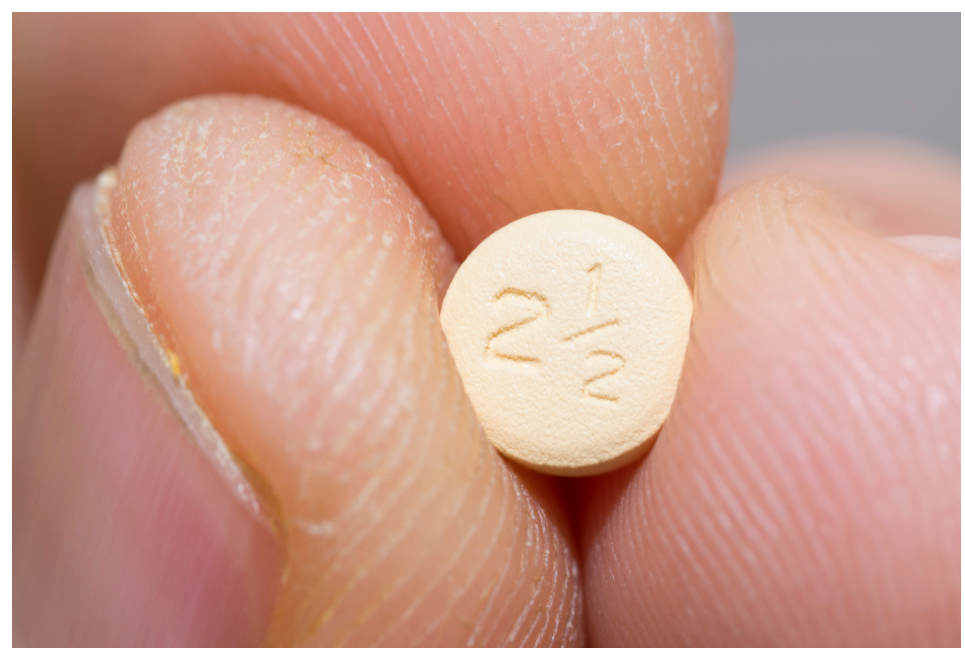

Direktevirkende perorale antikoagulasjonsmidler (DOAK), her apixaban. Illustrasjonsfoto: Science Photo Library

I en retrospektiv studie fra Taiwan ønsket forfatterne å kartlegge om samtidig bruk av de nye direktevirkende perorale antikoagulasjonsmidlene (direct oral anticoagulants, DOAK) i kombinasjon med andre medikamenter gir $ø$ kt risiko for store blødninger sammenlignet med DOAK-midler alene (1). Studien omfattet flere enn 90 ooo pasienter.

Pasienter som brukte DOAK-midler i kombinasjon med amiodaron, flukonazol, rifampicin eller fenytoin, var signifikant hyppigere i kontakt med sykehus på grunn av blødning. Blødningsforekomsten ved bruk av DOAK-midler i kombinasjon med atorvastatin, digoksin, erytromycin eller klaritromycin var signifikant lavere, mens det var ingen forskjell mellom bruk av DOAK-midler alene og i kombinasjon med verapamil, diltiazem, ciklosporin, ketokonazol, itrakonazol, vorikonazol, posakonazol eller dronedaron.

- Det er overraskende at kombinasjonen av DOAK-midler og amiodaron medfører $ø \mathrm{kt}$ blødningstendens, samtidig som atorvastatin, verapamil, diltiazem eller digoksin ikke medfører økt risiko, sier Dan Atar, professor ved Hjertemedisinsk avdeling, Oslo 
universitetssykehus, Ullevål. - Disse midlene blir ofte brukt i kombinasjon med DOAKmidler ved atrieflimmer.

- Vi har i mange tiår vært klar over muligheten for interaksjoner mellom warfarin (Marevan) og amiodaron. Som klinisk rutine har vi tilpasset warfarindoseringen ved oppstart av amiodaronbehandlingen og innkalt pasientene til hyppigere INR-kontroller. Klinikere må også ta høyde for $ø$ kt blødningstendens hos pasienter som behandles med DOAK-midler og amiodaron, sier Atar.

\section{LITTERATUR:}

1. Chang S-H, Chou I-J, Yeh Y-H et al. Association between use of non-vitamin K oral anticoagulants with and without concurrent medications and risk of major bleeding in nonvalvular atrial fibrillation. JAMA 2017; 318:1250 - 9. [PubMed][CrossRef]

Publisert: 28. november 2017. Tidsskr Nor Legeforen. DOI: 10.4045/tidsskr.17.0907

(C) Tidsskrift for Den norske legeforening 2020. Lastet ned fra tidsskriftet.no 